\title{
Carbon stable isotopic composition of soluble sugars in Tillandsia epiphytes varies in response to shifts in habitat
}

\author{
Laurel K. Goode • Erik B. Erhardt • \\ Louis S. Santiago $\cdot$ Michael F. Allen
}

Received: 11 March 2009/Accepted: 25 January 2010/Published online: 13 February 2010

(C) The Author(s) 2010. This article is published with open access at Springerlink.com

\begin{abstract}
We studied C stable isotopic composition $\left(\delta^{13} \mathrm{C}\right)$ of bulk leaf tissue and extracted sugars of four epiphytic Tillandsia species to investigate flexibility in the use of crassulacean acid metabolism (CAM) and $\mathrm{C}_{3}$ photosynthetic pathways. Plants growing in two seasonally dry tropical forest reserves in Mexico that differ in annual precipitation were measured during wet and dry seasons, and among secondary, mature, and wetland forest types within each site. Dry season sugars were more enriched in ${ }^{13} \mathrm{C}$ than wet season sugars, but there was no seasonal difference in bulk tissues. Bulk tissue $\delta^{13} \mathrm{C}$ differed by species and by forest type, with values from open-canopied wetlands more enriched in ${ }^{13} \mathrm{C}$ than mature or secondary forest types. The shifts within forest habitat were related to temporal and spatial changes in vapor pressure deficits (VPD). Modeling results estimate a possible $4 \%$ increase in the proportional contribution of the $\mathrm{C}_{3}$ pathway during the wet season, emphasizing that any seasonal or habitat-
\end{abstract}

Communicated by R. Sage.

L. K. Goode $(\bowtie)$

Biology Department, University of California,

Riverside, CA 92521, USA

e-mail: 1salz001@ucr.edu

L. K. Goode $\cdot$ L. S. Santiago $\cdot$ M. F. Allen

Center for Conservation Biology,

University of California, Riverside, CA 92521, USA

E. B. Erhardt

Department of Mathematics and Statistics,

University of New Mexico, Albuquerque,

NM 87131-0001, USA

\section{S. Santiago}

Department of Botany and Plant Sciences,

University of California, Riverside, CA 92521, USA mediated variation in photosynthetic pathway appears to be quite moderate and within the range of isotopic effects caused by variation in stomatal conductance during assimilation through the $\mathrm{C}_{3}$ pathway and environmental variation in VPD. $\mathrm{C}$ isotopic analysis of sugars together with bulk leaf tissue offers a useful approach for incorporating short- and long-term measurements of $\mathrm{C}$ isotope discrimination during photosynthesis.

Keywords Crassulacean acid metabolism - Mexico . Seasonally dry tropical forest $\cdot$ Stable isotope

\section{Introduction}

Crassulacean acid metabolism (CAM), a water-conserving mode of photosynthesis whereby plants take up $\mathrm{CO}_{2}$ at night, has been under investigation since its discovery over 200 years ago (Winter and Smith 1996). It has evolved multiple times in nearly 30 plant families, both terrestrial and aquatic (Crayn et al. 2004; Lüttge 2004), and is found in at least $6 \%$ of all vascular plant species (Ehleringer and Monson 1993). There are four phases of CAM: (1) nighttime $\mathrm{CO}_{2}$ uptake and fixation by phosphoenolpyruvate carboxylase (PEPC), (2) early morning $\mathrm{CO}_{2}$ uptake and fixation by ribulose 1,5-bisphosphate carboxylase/oxygenase (Rubisco), (3) daytime decarboxylation and refixation of $\mathrm{CO}_{2}$ under closed stomates, and (4) late afternoon $\mathrm{CO}_{2}$ uptake and fixation by Rubisco (Griffiths et al. 2002; Lüttge 2004). Although CAM is typically defined as nighttime $\mathrm{CO}_{2}$ uptake, in many CAM species, daytime $\mathrm{CO}_{2}$ fixation by Rubisco raises questions as to whether the amount of $\mathrm{CO}_{2}$ fixed through the $\mathrm{C}_{3}$ pathway varies with environmental conditions (e.g., Nobel et al. 1992; Winter and Holtum 2002; Winter et al. 2008). The significance of 
variation in activity of Rubisco in strong CAM plants has not yet been fully incorporated into an ecological framework.

The $\mathrm{C}$ stable isotopic composition $\left(\delta^{13} \mathrm{C}\right)$ of plant material can be used as an indicator of the relative proportion of $\mathrm{CO}_{2}$ assimilated by $\mathrm{CAM}$ and $\mathrm{C}_{3}$ photosynthetic pathways because of differential discrimination by the two carboxylating enzymes, PEPC and Rubisco. If only Rubisco is used, as occurs during light $\mathrm{CO}_{2}$ fixation, the $\delta^{13} \mathrm{C}$ of bulk plant material will be close to $-27 \%$. In contrast, if only PEPC is used, as occurs during dark $\mathrm{CO}_{2}$ fixation, the $\delta^{13} \mathrm{C}$ of plant material will be near $-13 \%$. Foliar $\delta^{13} \mathrm{C}$ values therefore reflect the weighting of these two processes (Farquhar et al. 1989). A mixing model using plant $\delta^{13} \mathrm{C}$ values in combination with $\mathrm{CAM}$ and $\mathrm{C}_{3}$ can provide information on the proportional use of the two photosynthetic pathways. Moreover, taking into consideration variation in $\mathrm{C}_{3}$ and $\mathrm{CAM}$ activity can allow a more accurate description of the contribution of each photosynthetic pathway (Winter and Holtum 2002).

It has been estimated that about half of all species exhibiting CAM are epiphytes (Winter and Smith 1996; Zotz 2004). In a study conducted by Griffiths and Smith (1983), seven out of 17 obligate epiphyte species in the genus Tillandsia exhibited obligate $\mathrm{C}_{3}$ photosynthesis, as determined by $\delta^{13} \mathrm{C}$ values between -23 and $-35 \%$. The other ten Tillandsia species were deemed obligate CAM, with $\delta^{13} \mathrm{C}$ values of -10 to $-21 \%$. Values more negative than $-14 \%$, however, indicate the potential for daytime $\mathrm{CO}_{2}$ uptake and fixation by Rubisco during CAM phases 1 and 2. Other published $\delta^{13} \mathrm{C}$ values for species of Tillandsia show that this genus spans the range of values expected for CAM and $\mathrm{C}_{3}$ plants, including a number of potentially intermediate species (Medina 1974; Medina and Troughton 1974; Griffiths and Smith 1983).

The isotopic composition of bulk leaf tissue has commonly been used to determine photosynthetic pathways (Winter et al. 1983; Silvera et al. 2005). The $\delta^{13} \mathrm{C}$ of bulk leaf tissue is a time-integrated measure, describing relative photosynthetic pathway utilization and $\mathrm{CO}_{2}$ concentration at the site of carboxylation over relatively long time scales. The $\delta^{13} \mathrm{C}$ of leaf sugars, however, provides an indication of pathways used for $\mathrm{C}$ fixation on the day the leaf was collected (Brugnoli et al. 1988). We utilized these long- and short-term measures of $\mathrm{C}$ fixation to investigate photosynthetic variation between seasons and among forest types with contrasting microclimate. We expected that the mode of $\mathrm{C}$ assimilation is flexible, leading to: (1) less negative $\delta^{13} \mathrm{C}$ of bulk leaf tissues in drier habitats, indicating a greater relative proportion of $\mathrm{CO}_{2}$ fixation through the CAM pathway; and (2) less negative $\delta^{13} \mathrm{C}$ of sugars in the dry season than in the wet season, indicating greater utilization of CAM.

\section{Materials and methods}

\section{Study sites}

The study was conducted in two forests in the Yucatan Peninsula, Mexico. El Edén Ecological Reserve contains semi-deciduous lowland tropical forest (Gómez-Pompa et al. 2003), located on the northern Yucatan Peninsula, $45 \mathrm{~km}$ northwest of Cancun in Quintana Roo. The reserve encompasses 1,500 ha of mostly flat landscape, with shallow soils over limestone bedrock, and annual rainfall of 1,500-2,500 mm (Allen et al. 2005).

El Zapotal is a 2,358-ha reserve in the state of Yucatan, just south of Ria Lagartos, located less than $50 \mathrm{~km}$ northwest of El Edén and contains vegetation types comparable to El Edén with annual precipitation from 700 to $1,100 \mathrm{~mm}$ and median annual temperature of $26^{\circ} \mathrm{C}$ (Faller and Serralde 2005). Both reserves are considered seasonally dry tropical forests, characterized by a pronounced dry season with little rainfall. Within each ecological reserve, measurements were conducted in three locations classified as mature forest, secondary forest, or wetland area forest types (Table 1). Canopy openness is comparable between mature and secondary forest types and is greater in the wetland area. The mature forest comprises moderate to tall trees (to $20 \mathrm{~m}$ ) with a leaf area index (LAI) of $2.2 \mathrm{~m}^{2} \mathrm{~m}^{-2}$. The secondary forest is shorter $(8 \mathrm{~m})$ but contains a high density of stems and a slightly greater LAI of $2.5 \mathrm{~m}^{2} \mathrm{~m}^{-2}$. The wetlands comprise grasses, sedges, and short-statured
Table 1 Six sampling locations in seasonally dry tropical forests: these include three forest types within each of two ecological reserves in the northern Yucatan peninsula, Mexico. Abiotic measurements were made and leaf samples were collected in each location

\begin{tabular}{llll}
\hline Reserve & $\begin{array}{l}\text { Annual } \\
\text { precipitation }(\mathrm{mm})\end{array}$ & $\begin{array}{l}\text { Forest type; leaf } \\
\text { area index }\left(\mathrm{m}^{2} \mathrm{~m}^{-2}\right)\end{array}$ & $\begin{array}{l}\text { Approximate age } \\
\text { vegetation (years) }\end{array}$ \\
\hline El Edén & $1,500-2,500$ & Secondary; 2.5 & $\sim 16$ \\
& & Mature; 2.2 & $>100$ \\
El Zapotal & $700-1,100$ & Wetland; $<1$ & $>100$ \\
& & Secondary & $\sim 31$ \\
& & Mature & $>100$ \\
& & Wetland & $>100$ \\
\hline
\end{tabular}


trees and shrubs (2-6 m) with a LAI $<1 \mathrm{~m}^{2} \mathrm{~m}^{-2}$ (Vargas et al. 2008; Hasselquist et al., unpublished data).

\section{Microclimate}

Three temperature/relative humidity (RH) sensors (Hygrochron DS1923; Maxim Integrated Products, Sunnyvale, CA, USA) were placed in each forest type in each reserve, $1.2 \mathrm{~m}$ above the ground on the south-facing sides of trees. Hourly recordings were taken and data were averaged for each forest type in each reserve. Within the mature forest at El Edén, four sensors were used to capture a height gradient, placed at 50,100, 175, and $250 \mathrm{~cm}$ above the ground. Vapor pressure deficit (VPD) of the bulk air was calculated from temperature and humidity based on equations from Jones (1992).

Study species and leaf collection

Four Tillandsia species were tested for isotopic composition: Tillandsia balbisiana Schult., Tillandsia brachycaulos Schltdl., Tillandsia dasyliriifolia Baker, and Tillandsia fasciculata $\mathrm{Sw}$. Leaves were collected from three to five individuals per species per forest type in each reserve, if present, during two sampling periods, October 2007 (rainy season) and April 2008 (dry season). All leaves were collected between ground level and $2.5-\mathrm{m}$ height (where these species commonly occur), and height was recorded for each individual. For each individual plant, three leaves were collected and homogenized to make one sample.

Sample preparation and analysis

To determine bulk leaf $\mathrm{C}$ isotopic composition, leaves were dried at $70^{\circ} \mathrm{C}$ for $48 \mathrm{~h}$ and ground to a fine powder. Sub-samples of $7 \mathrm{mg}$ were processed with a continuous flow isotope ratio mass spectrometer. Leaf sugar $\mathrm{C}$ isotopic composition was determined after sugars were extracted following the protocol described by Brugnoli et al. (1988) and modified by S. Mambelli at the University of California, Berkeley. This process involved centrifugation of leaf material mixed with de-ionized water to extract leaf sugars. Sugars were purified using ion-exchange resins and immediately freeze-dried before isotope analysis. All samples were analyzed at the Center for Stable Isotope Biogeochemistry, University of California, Berkeley. $\mathrm{C}$ stable isotope ratios $\left(\delta^{13} \mathrm{C}\right)$ were expressed relative to the Vienna Pee Dee belemnite (VPDB) limestone standard:

$$
\begin{aligned}
\delta^{13} C_{\% o}= & \left(\left[{ }^{13} C /{ }^{12} C_{\text {sample }}\right] /\left[{ }^{13} C /{ }^{12} C_{\text {standard }}\right]-1\right) \\
& \times 1,000 .
\end{aligned}
$$

Statistical analyses

We performed both univariate and multivariate analyses to explain measured $\delta^{13} \mathrm{C}$ values. ANOVA was used to determine differences between groups (e.g., epiphyte species, forest types). Means were compared using a Tukey-Kramer honest significant difference test. These were run with JMP software (SAS Institute 2001). We also used a multivariate analysis of covariance (ANCOVA) model to predict the proportional contribution of $\mathrm{C}_{3}$ photosynthesis $\left(\right.$ prop $_{\mathrm{C} 3}$ ) to our measured CAM plants, given by the mixing model: $\operatorname{prop}_{\mathrm{C} 3}=\left(\delta^{13-}\right.$ $\left.C_{\text {obs }}-\delta^{13} C_{\mathrm{CAM}}\right) /\left(\delta^{13} C_{\mathrm{C} 3}-\delta^{13} C_{\mathrm{CAM}}\right)$. Because the proportional contribution of $\mathrm{C}_{3}$ is a linear combination of the observed $\delta^{13} \mathrm{C}$ and the endpoint $\delta^{13} \mathrm{C}$ values, inference about prop $_{\mathrm{C} 3}$ also applies to observed $\delta^{13} \mathrm{C}$, so that a significant increase in prop $_{\mathrm{C} 3}$ is equivalent to a significant decrease in $\delta^{13} \mathrm{C}$. The predictor variables included species, material (bulk vs. sugar), reserve, forest type, season, height, RH, temperature, and night/day VPD. For factor variables (e.g., species) one group was considered the baseline, the effect for which was incorporated in the model intercept term, and the effect of each was considered relative to the baseline. The baselines for our factor variables were species, T. balbisiana; material, bulk; location, El Edén; forest type, mature forest; and season, dry. We tested the interactions of all covariates, looked for outliers and multi colinearity, and checked the residuals for violations of model assumptions. The full model was first reduced by a backward stepwise procedure using the Akaike information criterion (AIC) and then further reduced manually by dropping the largest variable with $P$-value at least 0.05 . Because the linear model assumes that the mean structure is correct (i.e., the response is linearly related to the coefficients and the residuals are normally distributed), we used a non-parametric bootstrap with 10,000 iterations to check that assumptions were not violated and to validate our results (Davison and Hinkley 1997).

We evaluated published $\delta^{13} \mathrm{C}$ values for plants in the genus Tillandsia and assigned likelihood for use of either $\mathrm{CAM}$ or $\mathrm{C}_{3}$ photosynthetic pathway, based on the discrimination inherent to each. $\delta^{13} \mathrm{C}$ values greater than $-15 \%$ were considered mostly or all CAM, values less than $-23 \%$ o and lower were considered mostly or all $\mathrm{C}_{3}$, and values between -23 and $-15 \%$ were considered to be a mixture of $\mathrm{CAM}$ and $\mathrm{C}_{3}$. We used a bootstrap analysis on this range of endpoints to incorporate the variability in endpoint CAM and $\mathrm{C}_{3}$ values, in order to estimate the relative proportion of $\mathrm{C}_{3}$ photosynthesis in CAM plants with intermediate $\delta^{13} \mathrm{C}$ values for ANCOVA model validation. These analyses were performed with R 2.8.1 (R Development Core Team 2008). 


\section{Results}

Average RH measured along the low canopy vertical gradient within the mature forest was highest at $50 \mathrm{~cm}$ height ( $\sim 97 \%$ ) and decreased to $92 \%$ at $250 \mathrm{~cm}$ height. RH was $\sim 95 \%$ for both intermediate heights $(100$ and $175 \mathrm{~cm})$. Average daytime VPD in the wet season was highest in the wetland areas $(0.66 \pm 0.02 \mathrm{kPa})$ and lowest in the mature forests $(0.33 \pm 0.02 \mathrm{kPa})$, with secondary forests exhibiting intermediate values $(0.40 \pm 0.01 \mathrm{kPa})$. Average daytime VPD in the dry season showed a significant increase in the mature and secondary forests (to $0.60 \pm 0.02$ and $0.69 \pm 0.01 \mathrm{kPa}$, respectively), but changed little in the wetland area (to $0.55 \pm 0.02 \mathrm{kPa}$ ). Dry season values are based on forest types in El Edén only, as we were not able to visit El Zapotal during the dry season.

Based on bulk $\delta^{13} \mathrm{C}$, the four Tillandsia species we tested are CAM species, and all fall into the intermediate range, with values less than $-15 \%$ and greater than $-23 \%$ o (Table 2). The mean for each species, when averaged across a range of habitats, was between -17.39 and $-16.12 \%$ (Table 2).

One-way ANOVAs revealed that bulk $\delta^{13} \mathrm{C}$ did not differ significantly with season $\left(F_{1,95}=0.920 ; \quad P>0.340\right)$, whereas sugar $\delta^{13} \mathrm{C}$ showed significant seasonal variation $\left(F_{1,59}=9.905 ; P<0.003\right.$; Fig. 1 ; Table 3$)$, with a dry season mean $(-15.73 \pm 0.14 \%)$ greater than the wet season mean $(-16.42 \pm 0.16 \%)$. Bulk $\delta^{13} \mathrm{C}$ differed among species $\left(F_{3,93}=7.767 ; P<0.0001\right.$; Table 2$)$. The only differences in pairwise comparisons between species were that mean bulk $\delta^{13} \mathrm{C}$ of $T$. brachycaulos was significantly lower than those of $T$. dasyliriifolia and T. balbisiana. Bulk $\delta^{13} \mathrm{C}$ was statistically indistinguishable between reserves $\left(F_{1,95}=0.747 ; P>0.39\right.$; Fig. 2$)$. Bulk $\delta^{13} \mathrm{C}$ differed between forest types $\left(F_{2,93}=22.534 ; P<0.0001\right.$; Fig. 3a). All forests differed significantly from each other in bulk $\delta^{13} \mathrm{C}$ with the wetland having the highest values $(-15.84 \pm 0.17 \%)$, secondary forests having the lowest values $(-17.72 \pm 0.15 \%)$, and mature forests

Table 2 Bulk $\mathrm{C}$ contents and $\mathrm{C}$ stable isotope ratios $\left(\delta^{13} \mathrm{C}\right)$ measured from four commonly occurring Tillandsia species within seasonally dry tropical forests of Mexico

\begin{tabular}{lll}
\hline Species & $\mathrm{C}(\%)$ tw & $\delta^{13} \mathrm{C}(\%)$ versus VPDB \\
\hline Tillandsia balbisiana & $46.35 \pm 0.28$ & $-16.39 \pm 0.19$ \\
Tillandsia brachycaulos & $45.01 \pm 0.23$ & $-17.39 \pm 0.16$ \\
Tillandsia dasyliriifolia & $44.97 \pm 0.45$ & $-16.12 \pm 0.31$ \\
Tillandsia fasciculata & $45.90 \pm 0.40$ & $-16.67 \pm 0.28$
\end{tabular}

Values represent means for each species across the range of forest types (secondary, mature, wetland), $\pm 1 \mathrm{SE}$. $V P D B$ Vienna Pee Dee belemnite
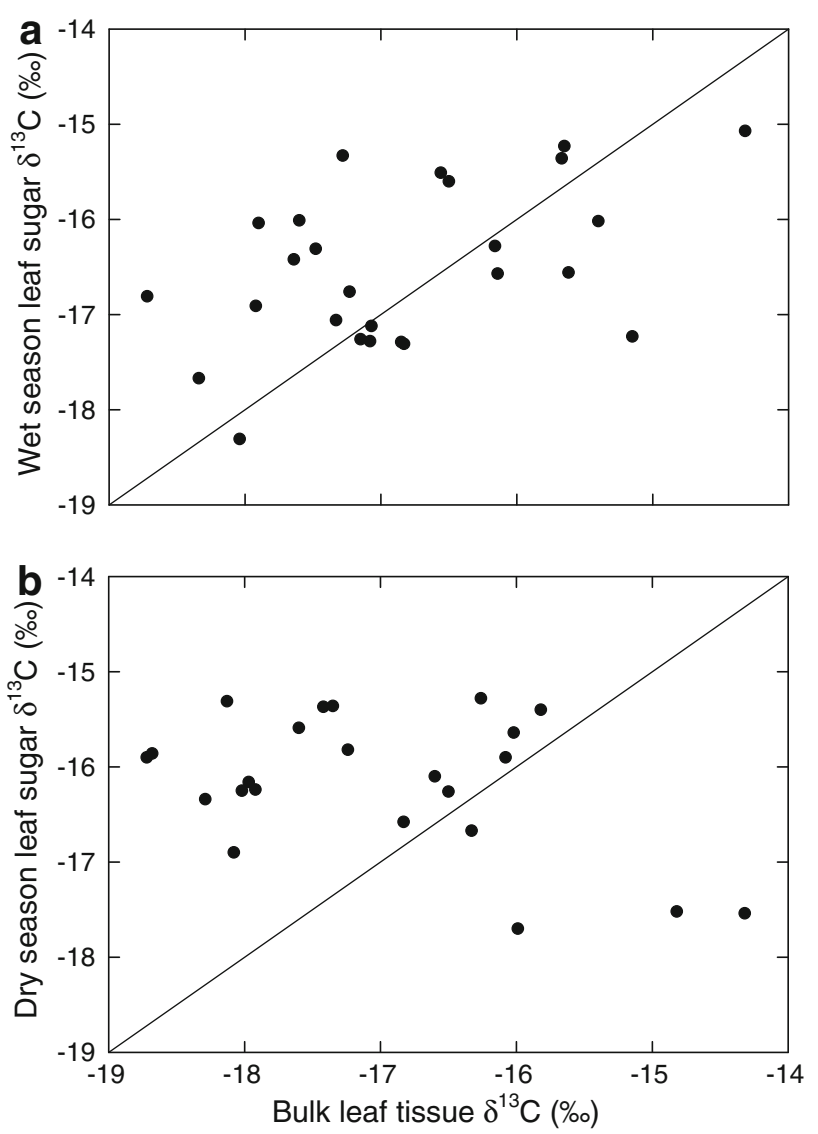

Fig. 1a, b $\mathrm{C}$ stable isotopic composition $\left(\delta^{13} \mathrm{C}\right)$ of leaf sugar versus bulk leaf $\delta^{13} \mathrm{C}$ for four Tillandsia species sampled in seasonally dry tropical forests of the Yucatan peninsula, Mexico. Lines represent 1:1 relationship. a Wet season sugars; values fall on 1:1 line. b Dry season sugars; values are heavier than for bulk leaf tissue

showing intermediate values $(-17.00 \pm 0.14 \%$; Figs. 2,3$)$. A two-way ANOVA using reserve, forest type, and a reserve by forest type interaction was significant $(F=16.382$; $P<0.0001)$, with all forest types in El Edén different at the $\alpha=0.05$ level and the wetland forest of El Edén significantly more enriched in ${ }^{13} \mathrm{C}$ than all forest types of $\mathrm{El}$ Zapotal. Sugar $\delta^{13} \mathrm{C}$ did not vary with height for either season $\left(F_{1,59}=2.878 ; P>0.09\right)$ whereas bulk $\delta^{13} \mathrm{C}$ was significantly related to height $\left[\delta^{13} \mathrm{C}=-17.48+0.006 \times\right.$ height $\left.(\mathrm{cm}) ; r^{2}=0.114 ; F_{1,95}=13.986 ; P<0.0003\right]$.

In the multivariate ANCOVA analysis, our reduced model included all five categorical variables and seven interactions (Table 4). The other variables (height, RH, temperature, and VPD) and interactions were dropped because of colinearity or no effect. Overall, the model had an $r^{2}$ of 0.607 and an adjusted $r^{2}$ of 0.566 (Table 4). The estimates for the indicator variables told us how different they were from the baseline variables (baseline estimates were 0 since they were included in the intercept). For example, conditional on the other factors, the bulk tissue 
Table 3 Seasonal shift in $\delta^{13} \mathrm{C}$ for bulk tissue and sugars of four Tillandsia species in the Yucatan peninsula, Mexico

\begin{tabular}{lll}
\hline Material & \multicolumn{2}{l}{$\delta^{13} \mathrm{C}(\%)$} \\
\cline { 2 - 3 } & Dry season & Wet season \\
\hline Bulk tissue & $-16.75 \pm 0.17$ & $-16.94 \pm 0.15$ \\
Sugars & $-15.73 \pm 0.14$ & $-16.42 \pm 0.16$
\end{tabular}

Means $\pm 1 \mathrm{SE}$

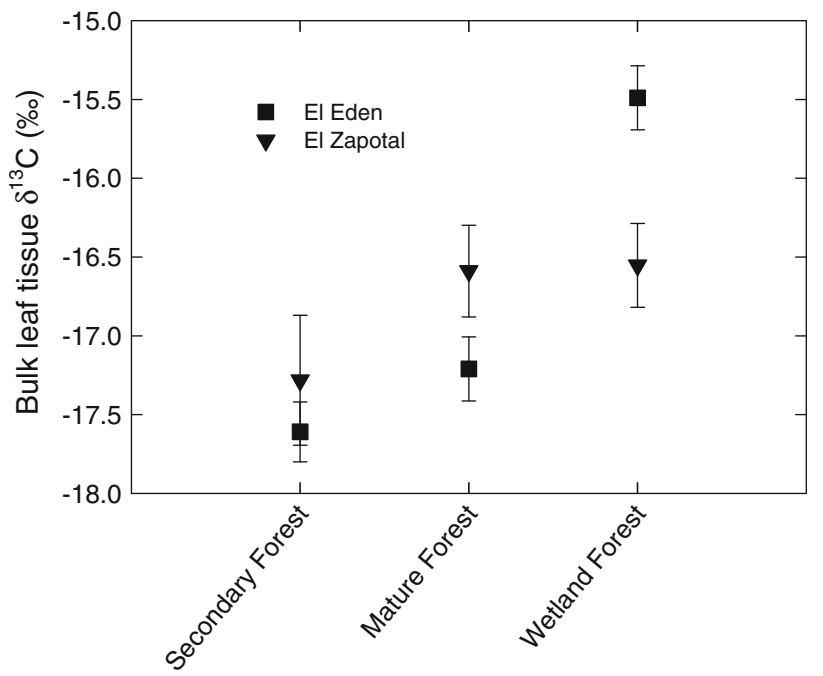

Fig. 2 Wet season bulk tissue C isotopic composition for Tillandsia species sampled from three forest types in two seasonally dry tropical forest of Mexico, El Edén and El Zapotal. Each point is the mean $\pm 1 \mathrm{SE}$

estimate for $T$. dasyliriifolia was very close to 0 , while the estimates for T. brachycaulos and T. fasciculata were 0.054 and 0.046 , respectively. At an $\alpha=0.05$ significance level, $T$. brachycaulos and $T$. fasciculata were statistically equivalent and significantly different from both $T$. dasyliriifolia and T. balbisiana (the baseline variable). Similarly, the model demonstrated that prop $_{\mathrm{C} 3}$ differed between species and between forest types, and the species effect on prop $_{\mathrm{C} 3}$ was modified for the sugar material (Table 4; $P<0.008)$. Forest type by season and reserve by forest type interactions were also important. The estimates for the main effects were consistent with expected trends of more enriched $\delta^{13} \mathrm{C}$ values under drier or greater VPD conditions. For example, El Zapotal, the drier reserve, had a negative estimate $(-0.037 ; P=0.066)$, suggesting there was less proportional contribution of $\mathrm{C}_{3}$ compared with $\mathrm{El}$ Edén, the wetter reserve. The wetland area also had a negative estimate $(-0.041 ; P=0.004)$, suggesting less $C_{3}$ contribution than the other forest types, consistent with greater VPD in this forest type. The wet season showed a positive estimate $(0.046 ; P=0.002)$, indicating that during the wet season, the proportional contribution of $\mathrm{C}_{3}$ photosynthesis increased.

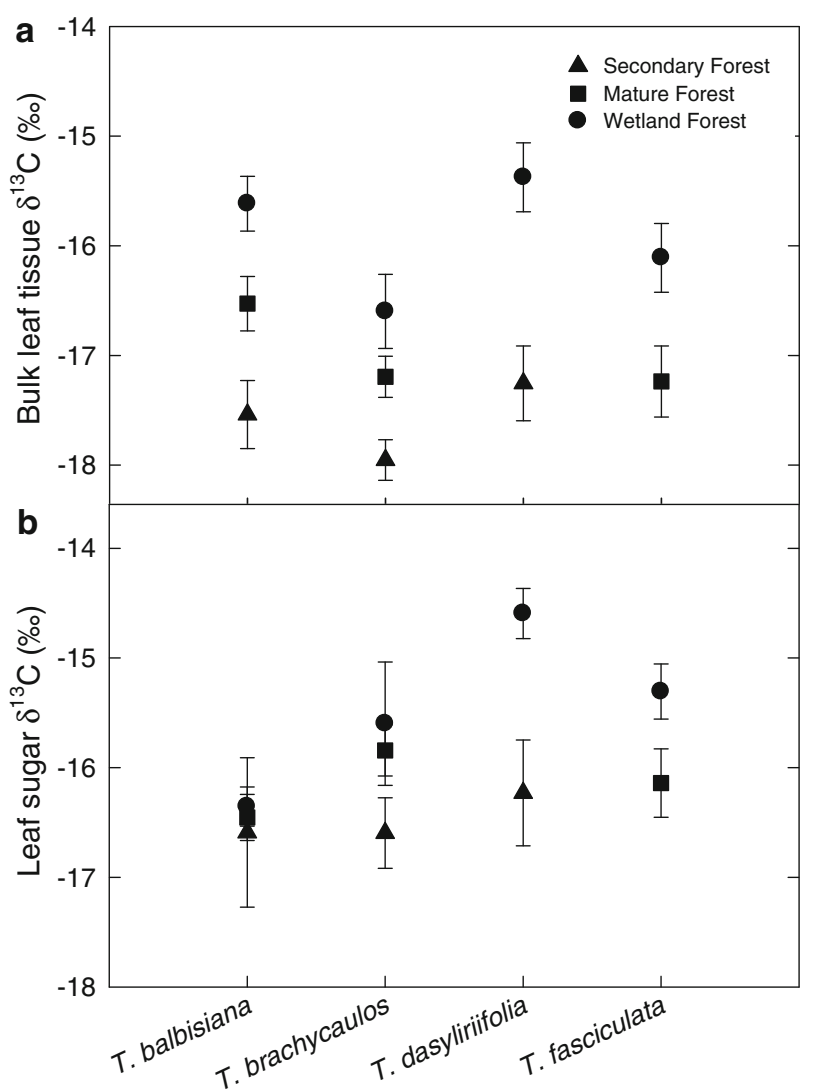

Fig. 3 Bulk (a) and sugar (b) C isotopic composition (mean $\pm 1 \mathrm{SE}$ ) for four species of Tillandsia in three forest types (secondary, mature, wetland) of seasonally dry tropical forests in the Yucatan peninsula, Mexico

The ANCOVA model estimates for the proportional contribution of $\mathrm{C}_{3}$ photosynthesis varied for the 24 possible combinations of species, forest type, and reserve (Fig. 4). For all species occurring in the mature forest, the estimated contribution of $\mathrm{C}_{3}$ was predicted to increase by about $4 \%$ during the wet season. Plants in the secondary forest were also predicted to utilize $\sim 3.5 \%$ more $\mathrm{C}_{3}$ in the wet season compared to the dry season. In contrast, the proportional contribution of $\mathrm{C}_{3}$ photosynthesis in wetland plants changed little with season. For T. balbisiana and T. brachycaulos, the two species found in mature forest of both reserves, individuals in El Zapotal were predicted to utilize 4\% less $\mathrm{C}_{3}$ than those in El Edén. Similarly, T. brachycaulos in secondary forests of both reserves was predicted to utilize $\sim 4.5 \%$ less $\mathrm{C}_{3}$ in El Zapotal (Fig. 4).

\section{Discussion}

This study utilized bulk tissue and sugar isotope ratios to test plasticity of photosynthetic pathways. Contrary to our expectations, the magnitude of isotope shifts observed 
Table 4 Reduced fitted model to explain measured $\delta^{13} \mathrm{C}$ values in four species of Tillandsia growing throughout mature, secondary, and wetland areas of the Yucatan peninsula

\begin{tabular}{|c|c|c|c|c|c|}
\hline Coefficients & Estimate & SE & $t$-value & $P(\geq t)$ & Significance \\
\hline Intercept & 0.213 & 0.0120 & 17.745 & 0.0000 & $* * *$ \\
\hline Material $=$ sugar & 0.011 & 0.0138 & 0.800 & 0.4249 & \\
\hline Season $=$ wet & 0.046 & 0.0143 & 3.184 & 0.0018 & $* *$ \\
\hline Reserve $=$ Zapotal & -0.037 & 0.0197 & -1.854 & 0.0658 & $\dagger$ \\
\hline Forest $=$ secondary & 0.051 & 0.0148 & 3.478 & 0.0007 & $* * *$ \\
\hline Forest $=$ wetland & -0.041 & 0.0141 & -2.928 & 0.0040 & $* *$ \\
\hline Species $=$ TIBR & 0.054 & 0.0123 & 4.388 & 0.0000 & $* * *$ \\
\hline Species $=$ TIDA & -0.005 & 0.0176 & -0.280 & 0.7796 & \\
\hline Species $=$ TIFA & 0.046 & 0.0165 & 2.763 & 0.0065 & $* *$ \\
\hline Sugar $\times$ TIBR & -0.095 & 0.0198 & -4.797 & 0.0000 & $* * *$ \\
\hline Sugar $\times$ TIDA & -0.068 & 0.0252 & -2.693 & 0.0079 & $* *$ \\
\hline Sugar $\times$ TIFA & -0.070 & 0.0247 & -2.847 & 0.0051 & $* *$ \\
\hline Wet $\times$ secondary & -0.012 & 0.0215 & -0.544 & 0.5870 & \\
\hline Wet $\times$ wetland & -0.057 & 0.0212 & -2.667 & 0.0085 & $* *$ \\
\hline Zapotal $\times$ secondary & -0.008 & 0.0339 & -0.250 & 0.8033 & \\
\hline Zapotal $\times$ wetland & 0.099 & 0.0272 & 3.630 & 0.0004 & $* * *$ \\
\hline
\end{tabular}

TIBA, T. balbisiana; TIBR, T. brachycaulos; TIDA, T. dasyliriifolia; TIFA, T. fasciculata;

** $P=0.01, * * * P=0.001,{ }^{\dagger} P=0.1$

Residual SE, 0.0492 on $144 d f$; multiple $r^{2}, 0.6071$; adjusted $r^{2}, 0.5662 ; F$-statistic, 14.83 on 15 and $144 d f ; P$ value, $<2.2 \times 10^{-16}$

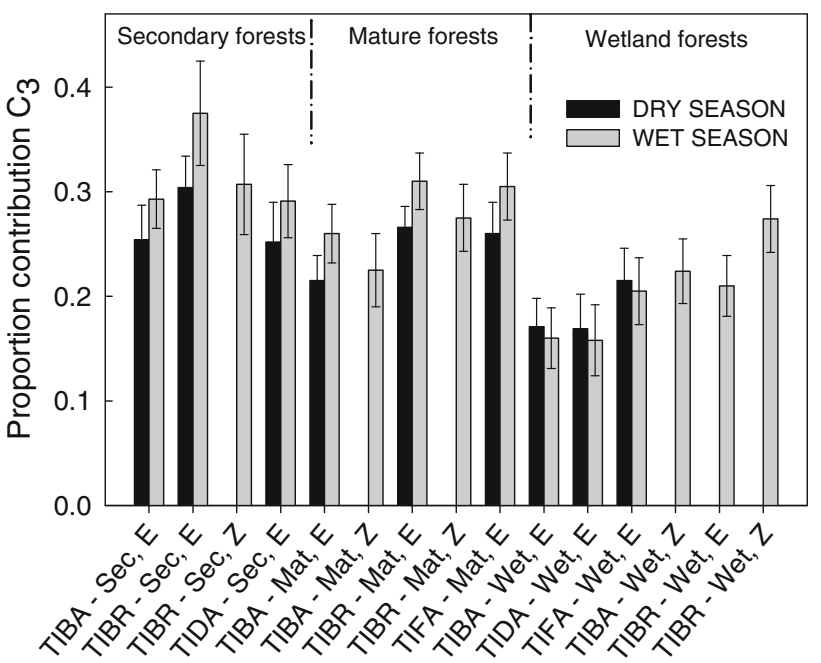

Fig. 4 Model-based estimated contribution of $\mathrm{C}_{3}$ photosynthesis $\pm \mathrm{SE}$ for different scenarios (combinations of variables) based on observed data from bulk tissue of Tillandsia species growing in seasonally dry tropical forests of the northern Yucatan peninsula, Mexico. TIBA T. balbisiana, TIBR T. brachycaulos, TIDA T. dasyliriifolia, TIFA T. fasciculata, Sec secondary forest, Mat mature forest, Wet wetland area, $E$ El Edén, Z El Zapotal

across habitat types and seasons was small, indicating that any seasonal and habitat-related shifts in the use of $\mathrm{C}_{3}$ and CAM pathways are moderate among Tillandsia species in our study sites. We found the $\delta^{13} \mathrm{C}$ values of dry season sugars to be significantly more enriched in ${ }^{13} \mathrm{C}$ than wet season sugars, consistent with assimilation of relatively more $\mathrm{CO}_{2}$ through the $\mathrm{C}_{3}$ pathway during the wet season, and potentially indicating differences in the use of photosynthetic pathways. However, the shifts in $\delta^{13} \mathrm{C}$ also fall within the range expected by physiological factors that affect $\mathrm{CO}_{2}$ concentration at the site of carboxylation, such as variation in stomatal conductance caused by changes in light environment, water availability, or VPD (Farquhar et al. 1982; Zimmerman and Ehleringer 1990). Nonetheless, the use of isotopic data derived from sugars holds promise as a method for assessing $\mathrm{C}$ isotope discrimination during photosynthesis on shorter timescales than those offered by bulk leaf sampling.

In CAM plants, differences in $\delta^{13} \mathrm{C}$ can be due to a number of factors, in addition to shifts in the degree of CAM activity. For example, there are established ontogenic and size-related effects on $\delta^{13} \mathrm{C}$ (Troughton et al. 1977; Kalisz and Teeri 1986; Zotz and Ziegler 1999; Holtum and Winter 2005; Winter et al. 2008). The plants tested in our sampling scheme were all of similar size and developmental stage, determined by the number and length of the leaves, thus eliminating size differences as a factor in our observed $\delta^{13} \mathrm{C}$ changes. Light environment can also influence $\delta^{13} \mathrm{C}$. For example, Skillman et al. (2005) showed that increased light resulted in more negative $\delta^{13} \mathrm{C}$ values for CAM plants and less negative $\delta^{13} \mathrm{C}$ values for $\mathrm{C}_{3}$ plants. The Tillandsia species we studied exhibit intermediate $\delta^{13} \mathrm{C}$ values around $-16 \%$ for bulk tissue, indicating they 
are CAM plants with some atmospheric $\mathrm{CO}_{2}$ assimilation through the $\mathrm{C}_{3}$ pathway. In our study, bulk tissue $\delta^{13} \mathrm{C}$ values were less negative in higher light (wetland forest), consistent with the direction of change in $\delta^{13} \mathrm{C}$ among $\mathrm{C}_{3}$ plants in the Skillman et al. (2005) study. Therefore, the isotopic differences between plants growing in the wetland forest type and those in the mature and secondary forest types may be reflective of the $\mathrm{C}_{3}$ mode operating at a lower internal $\mathrm{CO}_{2}$ :ambient $\mathrm{CO}_{2}\left(c_{\mathrm{i}} / c_{\mathrm{a}}\right)$ ratio in the higher light environment (Zimmerman and Ehleringer 1990).

Leakage of $\mathrm{CO}_{2}$ during decarboxylation could also lead to more negative $\delta^{13} \mathrm{C}$ values (Farquhar 1983; Pierce et al. 2002). If this were a factor in our study, we would expect leakage to occur similarly during both the wet and the dry seasons. However, leakiness cannot be ruled out from influencing the $\mathrm{C}$ isotope ratios across seasons due to the possibility for variation in $\mathrm{CO}_{2}$ leakage to occur with changes in stomatal conductance or the amount of Rubisco (von Caemmerer et al. 1997), both of which may vary with environmental conditions and nutrient availability (Tissue et al. 1993), and the concentration of $\mathrm{CO}_{2}$ in the bundle sheath cells.

The isotopic composition of source air can contribute to differences in $\delta^{13} \mathrm{C}$ of plant tissue because respired air from the soil surface is depleted in $\delta^{13} \mathrm{C}$ (Medina and Minchin 1980; Medina et al. 1991; Berry et al. 1997). Variation in leaf $\delta^{13} \mathrm{C}$ can therefore be caused by: (1) physiological processes, and/or (2) source $\delta^{13} \mathrm{C}$ of the atmosphere. In a comparison across canopy types, Buchmann et al. (2002) reported that $70 \%$ of the variation in $\delta^{13} \mathrm{C}$ was due to differential discrimination of the heavier isotope and $30 \%$ was due to source air. They show that for forests with a LAI less than $2.5 \mathrm{~m}^{2} \mathrm{~m}^{-2}$ and for canopy height over $1 \mathrm{~m}$, differences in $\delta^{13} \mathrm{C}$ would be negligible. The seasonally dry tropical forest types in our study are relatively open, with LAI $\leq 2.5 \mathrm{~m}^{2} \mathrm{~m}^{-2}$, and most of our samples were collected between 1- and 2.5-m height. Thus, our sampling scheme suggests that the effects of respired $\mathrm{CO}_{2}$ influencing the $\delta^{13} \mathrm{C}$ of source air is likely negligible, and that the observed $\delta^{13} \mathrm{C}$ values reflect physiological processes, similar to Mooney et al. (1989) who conducted their study in a comparable seasonally dry forest in Mexico.

Finally, we noted that the reduction in isotope values during the wet season was quite small, and could possibly be explained by greater stomatal conductance during the $\mathrm{C}_{3}$ mode of photosynthesis, rather than a shift in the ratio of initial fixation by PEPC versus Rubisco. Because stomatal conductance can vary depending on irradiance and VPD (Farquhar et al. 1982), we cannot rule this out as a factor affecting $\delta^{13} \mathrm{C}$. Direct measurements of gas exchange are necessary to distinguish between variation in $\mathrm{C}$ isotope ratios caused by changes in $c_{\mathrm{i}} / c_{\mathrm{a}}$ versus photosynthetic pathway.
Changes in the $\mathrm{C}$ isotopic composition of Tillandsia species over a range of environmental conditions were observed. To our knowledge, this is the first study to use sugar and bulk $\mathrm{C}$ isotope ratios in contrasting habitats within tropical forests to investigate photosynthetic plasticity and epiphyte physiology. We emphasize that gas exchange measurements will improve the ability to pinpoint mechanisms of seasonal or habitat-mediated shifts in $\mathrm{C}$ isotopic composition of sugars. Although in our system, any seasonal or habitat-mediated variation in photosynthetic pathway appears to be quite moderate, $\mathrm{C}$ isotopic analysis of sugars in conjunction with bulk leaf isotopic measurements offers a valuable future approach for incorporating short- and long-term measurements of $\mathrm{C}$ isotope discrimination during photosynthesis.

Acknowledgments We gratefully acknowledge the funding support of a 2007 UC MEXUS Dissertation Research Grant and National Science Foundation awards DEB-0706813, DEB-0615427 and EF-0410408. Thanks to the administrators at El Edén and El Zapotal for allowing us to use the reserves, to $\mathrm{J}$ Andrews for discussions and for suggesting El Zapotal, and to Caroline DeVan for support and help with extracting sugars. We also thank Katia Silvera, two anonymous reviewers, and the editorial staff for their insightful suggestions and comments that improved the manuscript. The experiments described comply with the laws of the United States of America and Mexico.

Open Access This article is distributed under the terms of the Creative Commons Attribution Noncommercial License which permits any noncommercial use, distribution, and reproduction in any medium, provided the original author(s) and source are credited.

\section{References}

Allen MF, Allen EB, Gómez-Pompa A (2005) Effects of mycorrhizae and nontarget organisms on restoration of a seasonal tropical forest in Quintana Roo, Mexico: factors limiting tree establishment. Restor Ecol 13:325-333

Berry SC, Varney GT, Flanagan LB (1997) Leaf $\delta^{13}$ C in Pinus resinosa trees and understory plants: variation associated with light and $\mathrm{CO}_{2}$ gradients. Oecologia 109:499-506

Brugnoli E, Hubick KT, von Caemmerer S, Wong SC, Farquhar GD (1988) Correlation between carbon isotope discrimination in leaf starch and sugars of $\mathrm{C}_{3}$ plants and the ratio of intercellular and atmospheric partial pressures of carbon dioxide. Plant Physiol 88:1418-1424

Buchmann N, Brooks JR, Ehleringer JR (2002) Predicting daytime carbon isotope ratios of atmospheric $\mathrm{CO}_{2}$ within forest canopies. Funct Ecol 16:49-57

Crayn DM, Winter K, Smith JAC (2004) Multiple origins of crassulacean acid metabolism and the epiphytic habit in the Neotropical family Bromeliaceae. PNAS 101:3703-3708

Davison AC, Hinkley DV (1997) Bootstrap methods and their application. Cambridge University Press, Cambridge

Ehleringer JR, Monson RK (1993) Evolutionary and ecological aspects of photosynthetic pathway variation. Annu Rev Ecol Syst 24:411-439

Faller JC, Serralde RR (2005) Programa de conservacion y manejo de la reserva privada "El Zapotal". Pronatura, Peninsula de Yucatan 
Farquhar GD (1983) On the nature of carbon isotope discrimination in $\mathrm{C}_{4}$ species. Aust J Plant Physiol 10:205-226

Farquhar GD, O'Leary MH, Berry JA (1982) On the relationship between carbon isotope discrimination and the intercellular carbon dioxide concentration in leaves. Aust J Plant Physiol 9:121-137

Farquhar GD, Ehleringer JR, Hubick KT (1989) Carbon isotope discrimination and photosynthesis. Annu Rev Plant Physiol 40:503-537

Gómez-Pompa A, Allen MF, Fedick SL, Jimenez-Osornio JJ (2003) The lowland Maya area: three millennia at the human-wildland interface. Haworth, Binghamton

Griffiths H, Smith JAC (1983) Photosynthetic pathways in the Bromeliaceae of Trinidad: relations between life-forms, habitat preference and the occurrence of CAM. Oecologia 60:176-184

Griffiths H, Helliker B, Roberts A, Haslam RP, Girnus J, Robe WE, Borland AM, Maxwell K (2002) Regulation of Rubisco activity in crassulacean acid metabolism plants: better late than never. Funct Plant Biol 29:689-696

Holtum JAM, Winter K (2005) Carbon isotope composition of canopy leaves in a tropical forest in Panama throughout a seasonal cycle. Trees 19:545-551

Institute SAS (2001) User's guide for JMP v.4.0.4. SAS Institute, Cary

Jones HG (1992) Plants and microclimate. University Press, Cambridge

Kalisz S, Teeri JA (1986) Population-level variation in photosynthetic metabolism and growth in Sedum wrightii. Ecology 67:20-26

Lüttge U (2004) Ecophysiology of crassulacean acid metabolism (CAM). Ann Bot 93:629-652

Medina E (1974) Dark $\mathrm{CO}_{2}$ fixation, habitat preference and evolution within the Bromeliaceae. Evolution 28:677-686

Medina E, Minchin P (1980) Stratification of $\delta^{13} \mathrm{C}$ values in leaves of Amazonian rain forests. Oecologia 45:377-378

Medina E, Troughton JH (1974) Dark $\mathrm{CO}_{2}$ fixation and the carbon isotope ratio in Bromeliaceae. Plant Sci Lett 2:357-362

Medina E, Sternberg L, Cuevas E (1991) Vertical stratification of $\delta^{13} \mathrm{C}$ values in closed natural and plantation forests in the Luquillo mountains, Puerto Rico. Oecologia 87:369-372

Mooney HA, Bullock SH, Ehleringer JR (1989) Carbon isotope ratios of plants of a tropical dry forest in Mexico. Funct Ecol 3:137-142

Nobel PS, Garciamoya E, Quero E (1992) High annual productivity of certain agaves and cacti under cultivation. Plant Cell Environ 15:329-335

Pierce S, Winter K, Griffiths H (2002) The role of CAM in high rainfall cloud forests: an in situ comparison of photosynthetic pathways in Bromeliaceae. Plant Cell Environ 25:1181-1189
Silvera K, Santiago LS, Winter K (2005) Distribution of crassulacean acid metabolism in orchids of Panama: evidence of selection for weak and strong modes. Funct Plant Biol 32:397-407

Skillman JB, Garcia M, Virgo A, Winter K (2005) Growth irradiance effects on photosynthesis and growth in two co-occurring shadetolerant Neotropical perennials of contrasting photosynthetic pathways. Am J Bot 92:1811-1819

R Development Core Team (2008) R: a language and environment for statistical computing. R Foundation for Statistical Computing, Vienna. ISBN 3-900051-07-0. http://www.R-project.org

Tissue DT, Thomas RB, Strain BR (1993) Long-term effects of elevated $\mathrm{CO}_{2}$ and nutrients on photosynthesis and Rubisco in loblolly pine seedlings. Plant Cell Environ 16:859-865

Troughton JH, Mooney HA, Berry JA, Verity D (1977) Variable carbon isotope ratios of Dudleya species growing in natural environments. Oecologia 30:307-311

Vargas R, Allen MF, Allen EB (2008) Biomass and carbon accumulation in a fire chronosequence of a seasonally dry tropical forest. Glob Chang Biol 14:109-124

von Caemmerer S, Millgate A, Farquhar GD, Furbank RT (1997) Reduction of ribulose-1,5-bisphosphate carboxylase/oxygenase by antisense RNA in the $\mathrm{C} 4$ plant Flaveria bidentis leads to reduced assimilation rates and increased carbon isotope discrimination. Plant Physiol 113:469-477

Winter K, Holtum JAM (2002) How closely do the $\delta^{13} \mathrm{C}$ values of crassulacean acid metabolism plants reflect the proportion of $\mathrm{CO}_{2}$ fixed during day and night? Plant Physiol 129:1843-1851

Winter K, Smith JAC (1996) An introduction to Crassulacean acid metabolism. Biochemical principles and ecological diversity. In: Winter K, Smith JAC (eds) Crassulacean acid metabolism. Springer, Berlin, pp 1-13

Winter K, Wallace BJ, Stocker GC, Roksandic Z (1983) Crassulacean acid metabolism in Australian vascular epiphytes and some related species. Oecologia 57:129-141

Winter K, Garcia M, Holtum JAM (2008) On the nature of facultative and constitutive CAM: environmental and developmental control of CAM expression during early growth of Clusia, Kalanchö, and Opuntia. J Exp Bot 59:1829-1840

Zimmerman JK, Ehleringer JR (1990) Carbon isotope ratios are correlated with irradiance levels in the Panamanian orchid Catasetum viridiflavum. Oecologia 83:247-249

Zotz G (2004) How prevalent is crassulacean acid metabolism among vascular epiphytes? Oecologia 138:184-192

Zotz G, Ziegler H (1999) Size-related differences in carbon isotope discrimination in the epiphytic orchid, Dimerandra emarginata. Naturwissenschaften 86:39-40 